\title{
Leif Wenar: Blood Oil: Tyrants, Violence, and the Rules that Run the World
}

New York: Oxford University Press, 2016, 494 p.

Contemporary philosophy has only recently started paying attention to natural resources from the perspective of justice. Leif Wenar's book Blood Oil published last year by Oxford University Press is a much welcome and original addition to this emerging discourse and it promises to redraw the contours of the debate on justice in general.

The book is a substantial extension of Wenar's influential article "Property Rights and the Resource Curse" from 2008. In this article, Wenar criticized the international trade for enabling sales of raw materials seized by illegitimate and corrupt governments or militias. He argued that natural resources of a country belong to its people and those regimes which do not have people's consent have no right to sell natural re-sources. Correspondingly, buyers purchasing from such regimes cannot obtain legal titles to these resources which are in essence "stolen goods." The reform Wenar pro-posed involves setting up a mechanism which indicates who is not a rightful seller of natural resources and punishes those who pursue commercial transactions with such a seller.

The book Blood Oil expands on these innovative ideas. Let me review what I believe are Wenar's most valuable contributions to the debate about natural resources: 1) the non-essentialist approach to natural resources, 2) the conception of popular sovereignty over natural resources, 3 ) the outline of the reform program.

Let me start with the approach to natural resources. Contemporary thinkers theoryzing about natural resources from the perspective of justice often assume, implicitly or uncritically, that there is something special about natural resources and that having them (or having an equal share of them) is instrumental in realizing justice. Natural resources are thus conceived of as a prominent distributive good and the question of natural resource justice is a question of distributive justice which, as many thinkers believe, should have a global scope (Beitz 1979, Steiner 2009, Armstrong 2017). Drawing on an extensive empirical material, Wenar convincingly proves this assumption as unsubstantiated. Natural resources have no essentialist connection to justice. Just as having and extracting them is not necessary for a country's success, it is also not sufficient for its failure. Developed countries such as Singapore and Switzerland (resource-poor) and USA, Canada, Australia, and Norway (resource-rich) demonstrate this fact (p. 6).

However, from the same empirical perspective, it is important to recognize that natural resources are often directly or indirectly related to injustice - authoritarianism, civil conflict, corruption, poverty, and terrorism. A large body of literature on the phenomenon of the resource curse has been demonstrating for decades 
how exactly and to what extent these connections occur. For those concerned with justice, Wenar suggests, the task is to look critically at what are the enabling mechanisms and institutional failures, and propose what to do about it, rather than to come up with purely moral reasoning about how to redistribute natural resources in an ideal world. The main accomplishment in his pursuit of this task is the elaboration of the conception of popular sovereignty over natural resources and the outline of the normative basis of the critique of the practices which violate this principle.

Wenar provides the critique of unjust power over resources before he outlines his conception of popular resource sovereignty. The key point of the critique (already outlined in the article) is the following: in many parts of the world, it is force, violence, or manipulation which vests rights to valuable natural resources. That "might makes right" as Wenar famously put it is reflected in the recognition of the power being the source of the legal title to resources by others. The recognition materializes through engagement in trade relations, especially through buying seized resources by purchasers who then claim unambiguous property rights to them. Examples still abound: oil, diamonds, and minerals sold by illegal militias or highly oppressive and corrupt regimes in Sierra Leone, Angola, Gabon, Nigeria, Equatorial Guinea, Democratic Republic of Congo are bought by corporations and governments and then transformed into consumer goods which are purchased and become individual property protected by property rights.

The fact that the international trading system allocates rights to natural resources to whomever is ruthless enough to commandeer those resources echoes the principle of effectiveness - a traditional principle of international law according to which an entity is recognized as a sovereign state and hence entitled to all the powers, rights, privileges, and immunities ascribed to states by international law if it has an effective control over the population and the territory. Wenar deconstructs the principle of effectiveness in several steps throughout the book: a) by exposing its Westphalian origin and history and showing how it provided legality to plunder, conquest, and enslavement; b) by arguing that it is no longer a valid principle of current international law based on the twin principles of human rights and popular sovereignty; c) by showing how its continuous existence of trading relations established on the basis of effecti-veness engenders injustice for the local populations for which we are then responsible; and d) how it creates externalities for "us" in the West - security and environmental risks, foreign policy dilemmas, and economic costs.

In the article, Wenar emphasized that the principle of effectiveness violates the most basic moral rule of market transactions, namely that only a rightful possession can become an object of sale and thus give rise to a valid title to purchased goods. That the people are the owners of their country's natural resources collectively had been casually introduced as a fact following from international law 
without much discussion. In the book, the conception of collective ownership of natural resources by a country's people gets extensive treatment and can be considered the major addition from the perspective of the debate about justice.

The key to Wenar's concept of popular sovereignty over natural resources is the interpretation of international law which accords the peoples the right to political self-determination and simultaneously the ownership of natural resources. Referring to the Article 1 in both human rights covenants and to other sources of international law, ${ }^{1}$ Wenar argues that these twin rights to political self-determination and collective ownership of natural resources are also linked to human rights - the right to self-determination being the first human right and human rights providing the "internal" scope of the collective self-determination.

Wenar interprets the twin rights of self-determination and ownership of natural resources as popular sovereignty over natural resources and argues that it involves two key principles - ownership and authorization. The ownership of natural resources implies that all of territory's natural resources are the property originally vested in the people and that the people have territorial jurisdictional rights over themselves and the resources. The authorization, following from ownership, is the right to authorize property laws and other decisions over resources.

In the next step, the argument is that the ownership of natural resources by the people and the right to authorize decisions about resources have to be respected by the state. So far, Wenar points out critically, dominant legal understanding has been unable to distinguish popular sovereignty from sovereignty of the state. Therefore, highly repressive states clearly violating popular sovereignty of its people are able to control and sell natural resources (and use the revenue for the perpetration of injustice) without being criticized for violating popular sovereignty over natural resources. The key to correcting this failure is to recognize the primacy of popular sovereignty over natural resources and define what kind of relationship there has to be between the people and the state so that popular sovereignty over resources is preserved in state decisions.

Wenar lays out the contours of the relationship by emphasizing four political conditions of possibility of popular authorization of resource management. They include information (access to information about the use of resources), indepen-

1 The Article 1 of Part I of both the International Covenant on Civil and Political Rights and the International Covenant on Economic, Social and Cultural Rights states that "all peoples have the right of self-determination and by virtue of that right they freely determine their political status and freely pursue their economic, social, and cultural development." Furthermore, "all peoples may, for their own ends, freely dispose of their natural wealth and resources without prejudice to any obligations arising out of international economic cooperation, based upon the principle of mutual benefit, and international law." (UN 1966a) and (UN 1966b). The Covenants entered into force on January 3 and March 23, 1976. 
dence (autonomy of the people and their not being subject to manipulation and propaganda), deliberation (possibility of a free discussion of the policies), and dissent (possibility of expressing opinion in ways that has impact on state policies). In concrete political terms, these conditions require that citizens must have at least bare-bones civil liberties and political rights. These conditions of authorization are non-negotiable and have precedence over other rights, for example social and economic rights the regime might fulfil - e.g. Saudi Arabia, a regime of benevolent despotism, which provides a range of social services to its citizens. Wenar insists that the absence of political rights and civil liberties means no authorization is given by the people and hence illegal exercise of resource sovereignty by the state.

The emphasis on a special category of rights in this section echoes the emphasis on people's consent to sales of natural resources by the state in the original article. However, it appears unsystematically connected to the previous emphasis on human rights as the "international standard of legitimate governance" (p. 151) or, as I would put it, the international standard of legitimacy of the exercise of sovereign rights, including rights to natural resources. Not only are civil and political rights not categorized explicitly within the totality of international legal human rights; they also seem to be given the precedence over other human rights. It is the latter point which certainly requires a more elaborate justification, especially given the growing international consensus on the equal importance of social and economic rights and hence indivisibility of human rights.

The last part of the book entitled Clean Trade sets out policies undermining trade with natural resources based on the rule of effectiveness. Wenar proposes the enactment of a Clean Trade Act which makes it illegal to purchase resources from a country that does not meet the minimal conditions for popular resource sovereignty, sets out penalties for doing so, and denies all commercial and financial facilities to vendors of a disqualified country. The act also declares all judicial venues of the home jurisdiction closed to the actors of a disqualified country. Standards of assessment of countries can be based on existing global public indicators and indexes (e.g. Freedom House Rating, World Bank/Brookings Institution Worldwide Governance Indicators, Resource Governance Index, Worldwide Governance Indicators, Transparency Interna-tional Corruption Perception Index, the Social Progress Index etc.).

Wenar also argues for the necessity of going beyond commercial disengagement with corrupt and illegitimate regimes and for creating a set of incentives for less principled countries to stop buying stolen resources. Clean Hands Trusts - funds acquired from duties on imports from countries which continue buying resources from repressive regimes (e.g. duties on Chinese imports to the U.S. worth of the value of oil China purchases from e.g. Equatorial Guinea). The second part of the Clean Trade framework consists in trade policies aimed at sustaining and encou- 
raging public accountability - the rules for the companies and agencies doing business in exporting country ("rules of engagement" which involve antibribery laws, transparency laws, money-laundering laws, demand for revenue distribution) and structuring trade policies with conditionalities (e.g. allowing trade privileges to countries that score higher on the rule of law index or demanding revenue distribution in exporting states (e.g. Oil-to-Cash system).

What needs to be appreciated first and foremost about Wenar's book is the fact that he locates the debate about natural resources and justice within the discourse about sovereignty, collective self-determination, and human rights and emphasizes the urgency of clarifying the permissible scope, conditions of legitimacy of exercise, and limits on sovereign rights to natural resources. Wenar relies on international law to provide normative basis to his conception of natural resource justice, in terms of who is the holder of rights to natural resources, what is the content of these rights, and what other principles of international law have bearing on this right. The effort to clarify the scope of existing sovereign rights to natural resources and mechanisms of enforcement of most fundamental limits as opposed to constructing purely moral rights wholly independent of the existing institutions will hopefully challenge the overwhelming reliance of the discourse about justice in philosophy on "practice-independent" normative principles.

However, quite a few questions and ambiguities concerning Wenar's conception of popular resource sovereignty persist. First, Wenar seems to equate the right to self-determination with popular sovereignty. To be sure, they are connected in this context - the principle of the permanent sovereignty over natural resources emerged as a corollary of the collective right to self-determination in the process of decolonization. The right to self-determination is nonetheless different from popular sovereignty. While the first means the right of collectives with political identity and history of domination and oppression to seek independence, popular sovereignty means that the people are the ultimate source of power of a government. The important difference is that the collective right to self-determination - its "internal" dimension, that is - can be interpreted in terms of human rights provided we focus on the right to self-determination as it exists in international law. Popular sovereignty and human rights are significantly more difficult to reconcile, however, and their compatibility is by no means accepted by political theory.

Second, Wenar confuses ownership rights, property rights, and jurisdictional rights over resources. To be sure, there are no widely accepted definitions. Recently, however, a number of scholars attempted to tackle different incidents of rights over natural resources and possible distinctions between various forms of ownership in natural resources (Risse 2012, Nine 2012, Moore 2015, Armstrong 2017). It would have reinforced the argument, had Wenar drawn on the available discussions. What needs to be questioned is whether property and ownership 
have identical meaning; and whether the concept of property is a plausible way of capturing human relationship with nature at all, especially given its association with discretionary nature of deci-sions made in the self-interest of the holder of given property rights. In any case, neither ownership rights nor property rights can be equated with jurisdictional rights which refer to rights of making legal rules. A meaningful way of interpreting this co-nundrum might be to argue that it is states which hold jurisdictional rights over resources (they include rights to determine the uses of natural resources including the property rights in them); and that the moral foundation of these rights is the collective ownership of natural resources by self-determining people.

Third and perhaps most important weak spot follows from these two points there is no discussion about the limits on popular sovereignty over natural resources. Wenar argues that ownership rights and jurisdictional rights over resources are "not necessarily unlimited" (p. 206) but he at the same time insists that there is only one limit on popular sovereignty which is "the people can't permanently cede law-making rights to the regime without negating its own sovereignty" (p. 223). By repeatedly emphasizing the ownership and property and freedom to dispose of natural resources, Wenar essentially says there are no limits on what people can actually do with their natural resources. This is untenable and it brings us paradoxically to the very beginning of the problem identified as the unjust and unlimited use of natural resources by the sovereign.

The lack of emphasis on limits to popular sovereignty might reflect the dominance of radical democratic theorizing about popular sovereignty and the prevalent understanding that popular sovereignty is incompatible with constitutionnalism and individual rights. If we accept there is a meaningful notion of popular sovereignty in constitutional democracy limited by individual rights - Wenar definitely seems to be buying into this notion by emphasizing civil liberties and political rights at one point and human rights at another - we have to insist that in the case of popular sovereignty over natural resources additional limits are necessary. Human rights limitations are insufficient. Nature and natural resources have distinct qualities - they are arbitrarily distributed on earth, are transboundary, their use creates externalities for other collectives, their subtraction might be unjust for other reasons. There is always at least one other rightful claimant, collective or individual, whose claims to natural resources belonging to a country's people cannot be easily dismissed - indigenous groups, humankind, global poor etc. Popular sovereigns are limited by those rightful demands; and it is a failure not to reflect on them systematically in a conception of popular resource sovereignty.

These issues reveal that the concepts and connections Wenar establishes require a more extensive analysis if they are to become common currency. I agree with Wenar that natural resources belong to a country's people if only because 
there has been an international consensus about it. I agree that powers and privileges of states have to be limited, among other things, by this territorial and collective popular "ownership" of natural resources and states who oppress their people cannot freely sell natural resources. I also agree that human rights are the most important international standards of legitimacy of the exercise of sovereign rights and privileges, including rights to natural resources. And I also find it unfortunate that these ideas are not widely accepted by those who develop concepttions of natural resource justice. To change the terms of the debate, however, these conceptions will require less narrative and more analytical approach. Clearly, Wenar has attempted to write Blood Oil in a strictly non-academic jargon, without conceptual ballast and excessive references to academic debates so that it is acessible to a larger public who is, after all, the key to changing patterns of consumption and policy. Political theorists and philosophers, however, will be left with quite a few unanswered questions.

Petra Gümplova

\section{References}

ARMSTRONG, Ch. (2017): Justice and Natural Resources: An Egalitarian Theory. New York: Oxford University Press.

BEITZ, Ch. (1990): Political Theory and International Relations. Princeton: Princeton University Press.

MOORE, M. (2015): A Political Theory of Territory. New York: Oxford University Press.

NINE, C. (2012): Global Justice and Territory. Oxford, UK: Oxford University Press. RISSE, M. (2012): On Global Justice. Princeton: Princeton University Press.

STEINER, H. (2009): Left Libertarianism and the Ownership of Natural Resources. In: Public Reason, 1 (1), 1-8.

WENAR, L. (2008): "Property Rights and the Resource Curse," In: Philosophy \& Public Affairs 36 (1), 2-32.

UN (1966a): Covenant on Economic, Social and Cultural Rights, Annex to General Assembly Resolution 2200 (XXI), 16 December 1966. Web. 8. March. 2016. <http://www.ohchr.org/EN/ProfessionalInterest/Pages/

CoreInstruments.aspx>.

UN (1966b): International Covenant on Civil and Political Rights, Annex to General Assembly Resolution 2200 (XXI), 16 December 1966. Web. 8. March. 2016. <http://www.ohchr.org/EN/ProfessionalInterest/Pages/ CoreInstruments.aspx>. 


\section{Petra Gümplova, Ph.D.}

Universität Erfurt

Max-Weber-Kolleg für kultur- und sozialwissenschaftliche Studien

Nordhäuser Str. 74

99089 Erfurt

Germany

petra.guemplova@uni-erfurt.de 